Andrii Kuzyshyn,

Professor of Geography, phD, Ternopil Volodymyr Hnatiuk National Pedagogical University, 2, M. Kryvonosa str., Ternopil, 46027, Ukraine

ORCID: 0000-0003-3879-7337

ResearcherID: AAF-1840-2019

\title{
ASSESSMENT OF TOURISM FLOWS WITHIN THE TERRITORY OF UKRAINE FROM THE SUSTAINABLE TOURISM DEVELOPMENT POINT OF VIEW
}

This study is devoted to the analysis of international tourism flows directed into Ukraine. Diagnostics of tourism flows according to regions of the world was carried out and the tendency of the increasing role of tourism both locally and internationally was noticed.

The results of the previous empirical study confirmed that different social groups have their own specific patterns of tourism activity. It also showed what groups responded the most to globalization and the possible consequences it may have for tourism activities.

Keywords: international tourism flows, tourism regions, motivation to travel, global imperatives, statistics of international tourism.

Relevance of the research topic. International tourism is driving economic, political, social and even cultural changes and contributing to the expansion of the single global market. It provides access to information and modern forms of communication as well as promotes spatial mobility of the population. This allows ideas to be shared freely, enabling people to become acquainted with new things and to formulate new attitudes and behaviours. At the same time, the development of tourism is impossible without normal inter-regional competition, that is, the progressive level of development of each tourism region, in our case - of each state, which depends on its ability to realize the existing tourism potential. Equally important is the development of inbound and inland tourism, which makes a significant contribution to the socio-economic development of the country, affecting local and state budget revenues, the development of entrepreneurship in the tourism and related spheres.

Formulation of the problem. Many contemporary determinants of tourism development can be considered within the economic, political, social and cultural dimensions of these processes. Being a very important component of modern world 
economy, tourism has attracted the attention of many researchers, who, in particular, seek to establish the economic relationship between tourism and global as well as regional processes of globalization. In the course of our research, we are planning to explore how the geography of the origin of tourists influences these processes in a particular country (on the example of Ukraine). Such studies make it possible to assess changes in the economic, social and political systems, as well as the culture of the country in general as well as its regions, and influence on the population worldwide (Bauman, 1999; Golka, 1999). This article aims to determine its impact on the tourism preferences of the residents of Ukraine and the orientation of their tourism activities (regarding socio-demographic characteristics).

Analysis of recent studies and publications. Many contemporary determinants of tourism development can be considered within the economic, political, social and cultural dimensions of these processes. Being a very important component of today\&apos;s world economy, tourism has attracted the attention of many researchers, who, in particular, seek to establish the economic relationship between tourism and global as well as regional processes of globalization. In the course of our research, we are planning to explore how the geography of the origin of tourists influences these processes in a particular country (on the example of Ukraine). Such studies make it possible to assess changes in the economic, social and political systems, as well as the culture of the country in general and its regions, and influence on the population worldwide (Bauman, 1999; Golka, 1999). This article aims to determine its impact on the tourism preferences of the residents of Ukraine and the orientation of their tourism activities (regarding socio-demographic characteristics).

It is the increase in spatial mobility of people, together with the increase in the number of business trips, that has led to the development of international tourism flows (Burns, Novelli, 2008). The reasons why people travel abroad more often are the gradual increase of integration and cooperation in the world economy and more frequent business contacts, as well as their desire to see new places. Travel frequency increases with distance, mainly through the development of telecommunications and transportation (Wahab and Cooper, 2001). In a world where airlines are reducing fares, travel time is getting shorter and shorter, developed societies are becoming richer and information is more readily available, short trips are being seen as a viable alternative to traveling within the country.

Analysing the tourism flows into Ukraine, it should be noted that this is a typical post-socialist country that is still gaining its «tourist image» and looking for a suitable tourist niche. Two circumstances play a paramount role: economic and political barriers that greatly impede outbound tourism and limit the geography of destinations (emphasis will be placed on Central and Eastern European countries). It is undoubted that the disintegration of the Communist bloc, the removal of political barriers and less burdensome formalities at the borders contributed to the increase in the intensity of outbound tourism. 
International tourism flows contributed to the formation of a new form of behaviour, a new cultural model that has long been studied by scholars (Burns and Novelli, 2006; Hall, Lew, 2009: 141-155, 2009: 141-185). The processes depend largely on the perception of the destination visited by tourists. This aspect was more widely discussed by M. Alvarez and G. Asugman (2006) who developed two models of tourists - researchers and planners. A. Dłużewska (2009) divided tourists into importers of culture and exporters of culture (the criterion for separation is the absorption of local cultural values).

It should be noted that international tourism flows should be regarded as a form of globalization that enhances environmental awareness and promotes the concept of sustainable development (Hall, Lew, 1998). The magnitudes of harmful and irreversible environmental changes that result from human activity are really alarming worldwide. The situation requires finding ways to restore the balance between the needs of people and the environment. The tourism industry is also paying attention to the concept of sustainable development. Awareness of the risks posed by too much tourist traffic makes the industry more prone to ensure that there is symmetry between the needs of tourists, the environment and local communities (Wahab, Pigram, 1997).

Another manifestation of globalization that has a significant impact on tourism and has been explored by B. Hołowiecka, E. Grzelak-Kostulska (Hołowiecka, Grzelak-Kostulska, 2013) is fashion that makes some tourism regions very popular; however, the popularity is often temporary. Particular social groups may have specific reasons why they find some destinations more attractive than others, such as prestige, sports activities (promotion of adventure tourism), and financial aspects (acceptable financial value). The young people who have access to information systems and know how to use them are probably the most sensitive to the newest fashion trends.

Regarding the territory of Ukraine, this issue was addressed in the study of N. Pogoda, O. Razmetova (2018), who focused on the analysis of tourist flows, diagnostics of the main activity indicators of the tourist activity subjects (the number of tourists served by the subjects of tourism activity and income of tourist enterprises by categories of legal entities and individuals). This allowed to carry out distribution of the number of tourist entities and to reveal the uneven state of such distribution on the regional level. The analysis provided the basis for making forecasts on the revenues from the provision of tourist services under three scenarios of development: pessimistic, realistic and optimistic.

O. Korol focused his research on these issues, including the formation of tourism flows under the influence of transport and geographical location, climatic conditions and level of well-being of the population. This allowed the author to carry out a cluster analysis of the relationship between tourist arrivals and income from foreign tourism. In this way, he defined the destinations of inbound tourist flows as a criterion for the tourist attractiveness of the territory. 
Partly this problem has already been addressed in the studies of A. Kuzyshyn and Y. Maryniak, however, at a regional level. They justified the dependence of the orientation and saturation of the tourism flow on the level of formation and comfort of tourist infrastructure (for example, the areas of the Western Ukrainian region). The authors emphasize the conditions of stay as one of the basic directions of international tourism flows.

Despite sufficient research, this issue remains relevant and in demand. Its relevance in Ukraine is related to the partial regional reorientation of international tourism flows and a significant change in the geography of the countries representing these tourists.

Thus, the aim of the study is to provide a more up-to-date view of the problem of tourism flows within one of the countries of the Central-Eastern European Tourism Sub-Region (using the UN WTO methodology).

\section{Presenting main material.}

General characteristics of tourism flows.

Travel flows are an indicator of the functioning of the tourism market, which is considered to be quite flexible, as it responds quickly both to changes in tourist demand and supply, and to changes in the environment (political, social, economic, geographical, socio-cultural). They serve as a litmus test of interest in a particular tourist destination.

\section{Activity of foreign tourists in Ukraine.}

The main feature of tourist activity among international tourists is the increase of spatial mobility of the population and the increase of distances that they overcome for the purpose of tourism visit. In the recent past, these factors could even be considered as those impeding tourist activities. Therefore, as one of the manifestations of globalization, the formation of tourism flows is a necessary assessment of the inclination of the population to travel abroad.

Numerous observations indicate that social groups differ in the use of tourism opportunities, especially with regard to trips. Important factors that make the difference are age, level of education and income. The highest mobility is observed among people aged 18-44 years, and the lowest - among the elderly.

The level of education is considered to be an important determinant of tourist activity, including the inclination of people to travel abroad. The study by B. Hołowiecka and E. Grzelak-Kostulska confirmed this view (Hołowiecka, GrzelakKostulska, 2013: 53). Although their studies took into consideration the territory of Poland, the Conclusion they have reached can be extrapolated to the territory of Ukraine - they found out that almost $40 \%$ of respondents are university graduates, $24 \%$ are people with secondary education and only $10 \%$ are tourists with basic professional education.

In terms of duration and frequency of trips, short-term trips were most typical for students and economically active people between the age of 18 and 44 years 
(maximum 3-day trips a couple of times a year). In older age groups, the frequency of short trips was lower. Longer travels exceeding 4 days showed a similar pattern. Again, youth was the most active. More than $70 \%$ of students went abroad at least «once every few years», every fourth - «once, twice a year» and about $7 \%$ «several times a year». The next age group (economically active population under the age of 44 years) in terms of characteristics and travel frequency was very similar to the previous one, but the rate of those who did not travel abroad was 35\%. The older age groups had a significantly higher percentage of respondents who did not travel abroad: more than $50 \%$ of the post-working age group and more than $86 \%$ of the $65+$ age group (Hołowiecka, Grzelak-Kostulska, 2013: 54). The data collected allow us not only to confirm age characteristics, but also indicate the relationship between the financial condition of households and their tourism activities.

The conclusion of their study is that past experience encourages people to visit new countries or regions. This is true for all ages, but the share of people who choose the global scale for their future travels is always more noticeable in the youngest age group and decreases with age. It is interesting to note that young people do not think that lack of experience can be a major problem in their tourism activity. One of the reasons for this optimism, backed up by the survey results, may be a lack of awareness of all the problems associated with short trips, especially to more remote destinations. Regardless of what such optimism is based on, it indicates that people have a positive attitude towards outbound tourism, which leads to the fact that they will continue to be active tourists.

Table 1

Classification of foreign citizens according to the purpose of arrival into Ukraine, 2006-2017, millions of people *

\begin{tabular}{|c|c|c|c|c|c|c|c|c|c|c|c|c|}
\hline & \multicolumn{12}{|c|}{ Years } \\
\hline & 2006 & 2007 & 2008 & 2009 & 2010 & 2011 & 2012 & 2013 & 2014 & 2015 & 2016 & 2017 \\
\hline $\begin{array}{l}\text { The } \\
\text { number } \\
\text { of foreign } \\
\text { citizens } \\
\text { entering } \\
\text { Ukraine- } \\
\text { total }\end{array}$ & $\begin{array}{l}\infty \\
\tilde{\sigma} \\
\infty\end{array}$ & 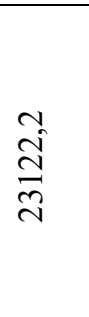 & $\begin{array}{l}\vec{a} \\
\dot{d} \\
\tilde{n}\end{array}$ & $\begin{array}{l}\text { m} \\
\infty \\
\stackrel{2}{\hat{~}} \\
\end{array}$ & 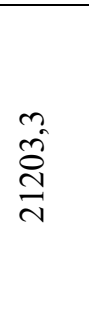 & $\frac{m}{\stackrel{n}{v}}$ & 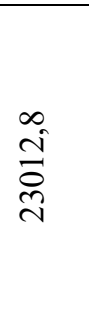 &  & $\frac{n}{\vec{\Xi}}$ & $\begin{array}{l}\underset{\infty}{\infty} \\
\stackrel{\sim}{ \pm} \\
\underset{=}{J}\end{array}$ & $\begin{array}{l}\vec{ल} \\
\hat{n}\end{array}$ & $\begin{array}{l}0 \\
\stackrel{\text { I }}{\text { İ }}\end{array}$ \\
\hline $\begin{array}{l}\text { Accor- } \\
\text { ding } \\
\text { to the } \\
\text { purpose } \\
\text { of the } \\
\text { stay }\end{array}$ & & & & & & & & & & & & \\
\hline
\end{tabular}




\begin{tabular}{|c|c|c|c|c|c|c|c|c|c|c|c|c|}
\hline & \multicolumn{12}{|c|}{ Years } \\
\hline & 2006 & 2007 & 2008 & 2009 & 2010 & 2011 & 2012 & 2013 & 2014 & 2015 & 2016 & 2017 \\
\hline $\begin{array}{l}\text { Official, } \\
\text { business, } \\
\text { diploma- } \\
\text { tic issues }\end{array}$ & 1011,2 & 909,0 & 1048,4 & 741,9 & 694,6 & 645,0 & 350,2 & 1674,2 & 494 & 41,2 & 33,4 & 89,0 \\
\hline Tourism & 1210,0 & 1445,0 & 1693,3 & 1350,0 & 1083,0 & 1222,6 & 940,0 & 488,5 & 146,8 & 137,9 & 172,8 & 39,0 \\
\hline $\begin{array}{l}\text { Private } \\
\text { issues }\end{array}$ & $\begin{array}{l}\text { â } \\
\tilde{n} \\
\tilde{\sigma}\end{array}$ & 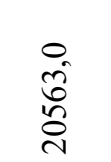 & $\begin{array}{l}\text { Oे } \\
\text { ते } \\
\text { ते }\end{array}$ & $\begin{array}{l}\vec{\infty} \\
\dot{\infty} \\
\infty \\
\infty\end{array}$ & $\begin{array}{l}\overrightarrow{\mathscr{O}} \\
\stackrel{0}{0}\end{array}$ & $\begin{array}{l}\vec{\infty} \\
\vec{\Omega}\end{array}$ & 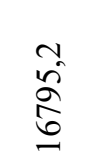 & $\begin{array}{l}\hat{\sigma} \\
\hat{\infty}\end{array}$ & $\begin{array}{l}\infty \\
\delta^{\circ} \\
\delta^{2}\end{array}$ & $\begin{array}{l}\text { } \\
\hat{n} \\
=\end{array}$ & $\begin{array}{l}\hat{\tilde{n}} \\
\hat{\beth}\end{array}$ & $\frac{\vec{v}}{\underset{\nabla}{\Delta}}$ \\
\hline Education & 45,3 & 49,5 & 65,2 & 103,5 & 67,5 & 59,2 & 23,8 & 0,3 & 1,1 & 0,1 & 2,1 & 4,5 \\
\hline Work & 4,6 & 7,8 & 12,0 & 31,8 & 14,8 & 16,1 & 9,1 & 0,3 & 0,8 & 1,3 & 0,0 & 2,6 \\
\hline $\begin{array}{l}\text { Immi- } \\
\text { gration }\end{array}$ & 15,8 & 24,0 & 27,8 & 8,6 & 48,3 & 64,8 & 40,4 & 5,1 & 0,2 & 2,3 & 3,1 & 4,0 \\
\hline $\begin{array}{l}\text { Cultural } \\
\text { and sport } \\
\text { exchange, } \\
\text { religion, } \\
\text { etc. }\end{array}$ & 96,6 & 123,9 & 311,3 & 214,5 & 206,1 & 224,1 & 485,4 & 584,2 & 281,4 & 720,2 & 167,9 & 348,9 \\
\hline
\end{tabular}

* based on the data from http://www.ukrstat.gov.ua/

We have analysed the tourist arrivals over the period 2006-2017. By 2013, there is a clear tendency to increase the number of foreign visitors coming into Ukraine from 19 million in 2006 to 24.7 million in 2013 (thus, the increase of arrival into the country during this time amounted to 30\%). 2014 and 2015 became the most crisis years in tourist arrivals into Ukraine, clearly reflecting the insecurity and uncertainty about the future associated with the war in eastern Ukraine. Since 2016, there has been a slow increase in absolute quantitative indicators of arrivals and in 2017, the attendance of Ukraine increased by 14\% compared to the lowest indicator in 2015.

An interesting criterion is the comparison of the arrival purpose of foreigners coming into Ukraine for the estimated period (Table 1). In 2006, slightly more than $6 \%$ of foreigners arrived for tourism purposes, at the same time the bulk of the arrivals were justified by private purposes (more than $87 \%$ ). More than $5 \%$ of business trips were made. In 2011, the share of those who came for tourism purposes decreased to $5.7 \%$, although the total number of arrivals increased. The share of private trips increased to $89.5 \%$ and business trips decreased to $3 \%$. In 2017 , the share of those who came for the tourist destination decreased sharply $(0.3 \%)$, which should be considered as a wake-up call (we will return to this issue a little later). There was a significant increase in the share of those who arrived for private purposes (96.6\%), which occurred at the expense of other categories of visitors (business trips, education, employment; the exception is the increase of trips for cultural, sport and religious purposes).

On Figure 1 a reduction in the number of tourists who travel to Ukraine is shown. However, the imperfection and opacity of statistical accounting does not allow 
us to rely on these indicators with certainty, since a significant proportion of those who declare another purpose (private, business trips, education, employment, trips for cultural, sport or religious purposes) necessarily combine staying with tourism and discovering the tourist attractions of Ukraine. But officially the tourism purpose of stay is rarely becoming the justification goal of the state.

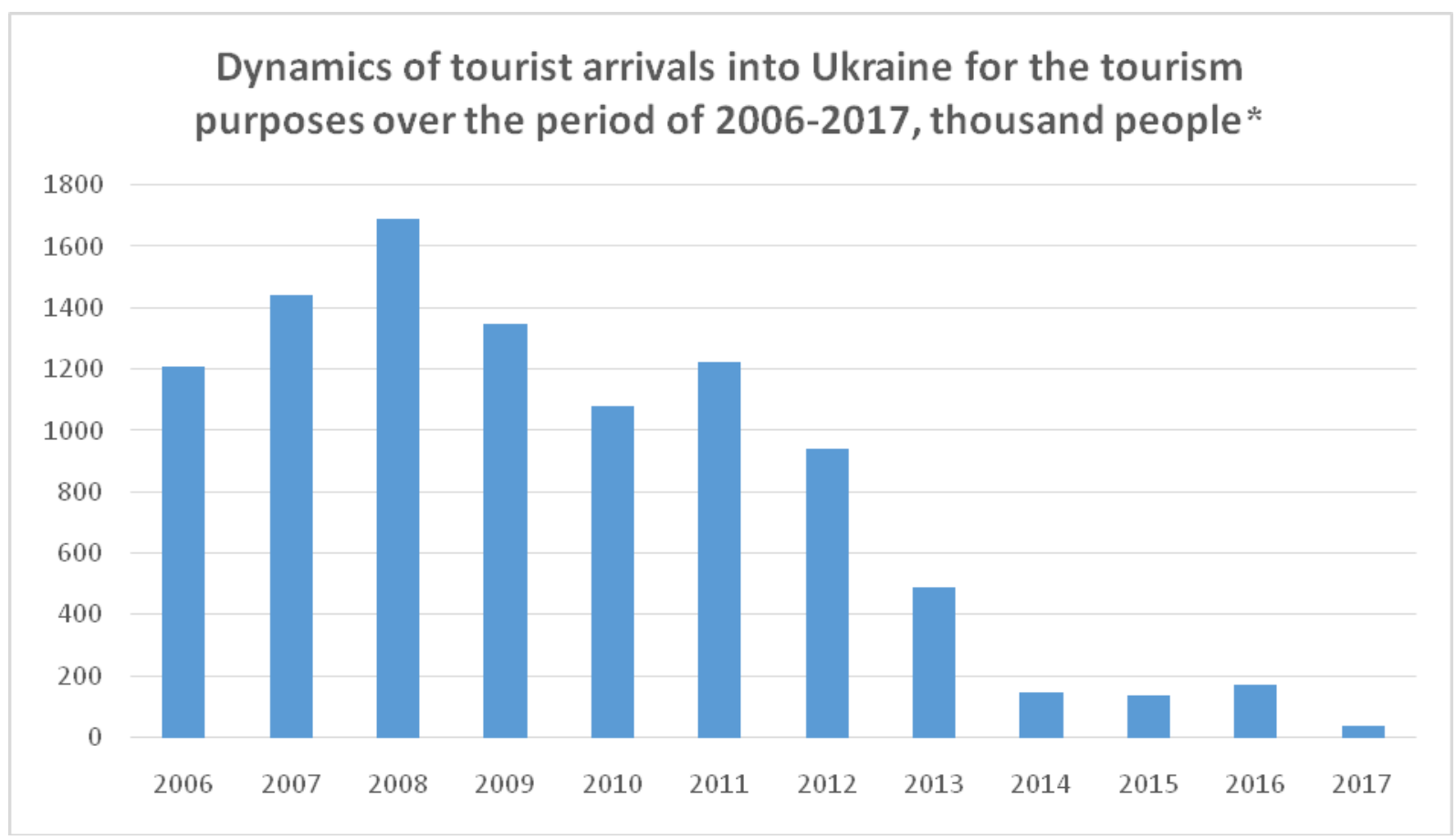

Fig. 1. Number of tourists who travel to Ukraine

Source: based on the data from http://www.ukrstat.gov.ua

There are several reasons why one can try to explain such negative dynamics. The majority of travellers with a private purpose are engaged in self-organization of the tourism format, which is why today in the world and in Ukraine, in particular, it facilitates the presence of specialized internet platforms, tourism blogs and simply forums for sharing impressions of tourists. Worldwide booking and transportation booking sites often provide related tourist services, which are also often referred to by foreigners. But, in general, for tourist oriented objects (tourist attractions, food establishments, leisure centres, event tourism resources), these trends play a positive role. Organizers of the tourism industry (tour operators and travel agents) and employees of the tourism industry (guides, etc.) suffer from such a process, which cannot always compete with the powerful online resources that offer such services. At the same time, it should encourage representatives of the tourism industry to form unique and original offers that would attract the attention of foreigners.

Geography of origin of tourists visiting Ukraine. The study also aimed at defining the interest to Ukraine from foreigners by assessing the geography of their native countries. 
In 2017, representatives of more than 130 countries visited Ukraine. Among the leading countries according to the number of visitors were Moldova (4435.6 thousand people), Belarus (2727.6 thousand people), Russia (1464.8 thousand people), Poland (1144.2 thousand people), Hungary (1119.4 thousand people), Romania (791.1 thousand people), Slovakia (366.2 thousand people), Turkey (270.7 thousand people), Israel (261.5 thousand people), Germany (209.4 thousand people), the United States (153.8 thousand people). Fortunately, the list has been completed over the recent years by representatives of Azerbaijan (96.0 thousand people), Italy (84.6 thousand people), Great Britain (78.6 thousand people), Lithuania (75.6 thousand people), France (61.0 thousand people) and the Czech Republic (67.7 thousand people). Before the war, in 2012 the geography of foreign tourists differed significantly: Russia (9526.7 thousand people), Moldova (4849.1 thousand people), Belarus (3091.8 thousand people), Poland (1404.1 thousand people), Romania (791.3 thousand people), Hungary (742.4 thousand people), Slovakia (476.6 thousand people), Germany (274.1 thousand people), the United States (134.1 thousand people), Uzbekistan (185.5 thousand), Turkey (117.1 thousand), Israel (107.1 thousand), Azerbaijan (101.2 thousand). It should be considered as a positive trend that there is an increase in the number of arrivals from the EU countries and the world. The negative thing is that there is the overall decrease in the number of arrivals into the country.

The characteristic features of the distribution of tourists according to tourism regions of the world have been developed (according to the UNWTO methodology). In each of the six tourism regions, we rated the top five countries according to the number of tourists who arrived into the country in 2006, 2012 and 2017. There are some regions where the leaders stayed the same all the time (countries in the American, South Asian and Asian-Pacific tourism regions). In the rest of the regions, the top leading countries have undergone minimal changes over the period.

Noteworthy is the proportion of tourists representing the five leading countries according to the arrivals into Ukraine in each tourism region for the specified period.

Tourist coming from the European tourism region (about $98 \%$ of all arrivals into the country) is a well-established trend. But if in 2006 the top five countries (Russia, Poland, Moldova, Belarus and Hungary) accounted to almost $90 \%$ in Ukraine, in 2012 this figure decreased to $86.5 \%$, and in 2017 - up to $68 \%$. This is not an indication of a decline in interest in Ukraine (except for the Russians, which is natural because of the war), but rather an indication of increased interest from other countries in the region, which is clearly a positive signal. Another undeniable fact is the increase in the number of countries in the region, from which more than 50 thousand tourists came: in 2006 - 13 countries, in 2012 - 20 countries, in 2017 - 14 countries (here should be emphasized the factor of war in the eastern Ukraine, which is definitely a deterrent element in the functioning of the tourism market). 
In the same context, it is interesting to analyse the number of tourists from the EU countries. In 2006, 6,681.4 thousand people arrived from these countries, representing $35.3 \%$ of the arrivals from the European tourism region. In 2012, this figure was 4324.5 thousand people or $31.1 \%$ of the European tourists. Thus, one can state that the European tourism region plays a dominant role in the formation of tourism flows and there was a certain reorientation of tourists - since the beginning of the XXI century until 2017. It is noticeable that the number of Russian and Belarusian tourists is decreasing and at the same time the number of tourists from the EU countries and other European countries, which traditionally bring more money to the country (the profit from one tourist arrival is higher), is increasing.

The US tourism region represents the second largest number of tourists coming into Ukraine, although their number is not too large. The top leaders in arrivals are stable (USA, Canada, Brazil, Argentina, Mexico) and they account for $98-99 \%$ of revenues from this region. However, it should be emphasized that in other countries of the world these countries send the main bulk of tourists from the American tourism region.

The main tourist countries of the Asian-Pacific region are stable (China, South Korea, Japan, Australia, Vietnam), but their share in the total flow decreases (2012 $87.5 \%, 2017-78 \%$ ). This can be considered a positive trend in the expansion of the number of tourists from this region of the world in general and the number of those interested in Ukraine in particular (the total profit for the specified period increased by $85 \%$ and has a constant positive tendency).

Other tourism regions of the world view Ukraine as a promising destination for international tourist arrivals, with a fairly stable range of tourism-forming countries. In the South Asian region, top countries include India, Iraq, Pakistan, Afghanistan and Bangladesh (the mentioned sequence corresponds to the number of tourists coming from these countries into Ukraine). In the African tourism region, Morocco, Nigeria, Tunisia are the leading countries in terms of arrivals, and Algeria, Mozambique, South Africa and the Republic of Cape Verde have been leaders in some years. For the Middle East tourism region, Egypt, Jordan, Iraq, Lebanon, Syria and Libya are the leading countries in this issue. As it is shown in Figure 2, the share of the last three tourism regions in international tourist arrivals into Ukraine is negligible. The same can explain the minimal global links between these countries and regions, and this is the reason why the cultures of Ukraine and of these regions are weakly interconnected.

According to the official statistics, in 2017, 58\% of tourists who visited Ukraine and were served by tour operators and travel agents mentioned treatment as the purpose of the trip. $39 \%$ of them determined leisure and entertainment for the purpose of travel and only $2.3 \%$ came for business or study purposes. In 2018, the situation has changed somewhat. Almost $70 \%$ of foreign tourists who visited Ukraine declared leisure and entertainment to be purpose of their travel. 


\section{Number of foreign tourists served by tour operators and travel agents of Ukraine in 2018}

\begin{tabular}{|c|c|c|c|c|c|c|c|c|}
\hline & & \multirow[b]{2}{*}{$\begin{array}{c}\text { Total } \\
\text { number of } \\
\text { tourists }\end{array}$} & \multicolumn{6}{|c|}{ According to the purpose of stay } \\
\hline & & & $\begin{array}{c}\text { Official, } \\
\text { business, } \\
\text { education }\end{array}$ & $\begin{array}{l}\text { Leisure, } \\
\text { enter- } \\
\text { tainment }\end{array}$ & $\begin{array}{l}\text { Treat- } \\
\text { ment }\end{array}$ & $\begin{array}{l}\text { Sport } \\
\text { tourism }\end{array}$ & $\begin{array}{l}\text { Spe- } \\
\text { cialized } \\
\text { tourism }\end{array}$ & others \\
\hline 1 & Ukraine & 72941 & 8031 & 58914 & 3883 & 235 & 283 & 159 \\
\hline 2 & Vinnytsia & - & & & & & & \\
\hline 3 & Volyn & 428 & - & 27 & 251 & 150 & - & - \\
\hline 4 & Dnipropetrovsk & - & - & - & - & - & - & - \\
\hline 5 & Donetsk & 11 & 11 & - & - & - & - & - \\
\hline 6 & Zhytomyr & - & - & - & - & - & - & - \\
\hline 7 & Transcarpathian & 173 & - & 173 & - & - & - & - \\
\hline 8 & Zaporizhzhia & 252 & 5 & 247 & - & - & - & - \\
\hline 9 & Ivano-Frankivsk & 3392 & - & 3392 & - & - & - & - \\
\hline 10 & Kyiv & 2 & - & 2 & - & - & - & - \\
\hline 11 & Kirovohrad & - & - & - & - & - & - & - \\
\hline 12 & Luhansk & - & - & - & - & - & - & - \\
\hline 13 & Lviv & 6395 & - & 3973 & 2327 & 55 & 40 & - \\
\hline 14 & Mykolayiv & - & - & - & - & - & - & - \\
\hline 15 & Odesa & 1938 & 69 & 1869 & - & - & - & - \\
\hline 16 & Poltava & - & - & - & - & - & - & - \\
\hline 17 & Rivne & - & - & - & - & - & - & - \\
\hline 18 & Sumy & - & - & - & - & - & - & - \\
\hline 19 & Ternopil & - & - & - & - & - & - & - \\
\hline 20 & Kharkiv & 154 & - & 154 & - & - & - & - \\
\hline 21 & Kherson & - & - & - & - & - & - & - \\
\hline 22 & Khmelnytskyi & - & - & - & - & - & - & - \\
\hline 23 & Cherkasy & 24 & - & 24 & - & - & - & - \\
\hline 24 & Chernivtsi & 137 & - & 137 & - & - & - & - \\
\hline 25 & Chernihiv & - & - & - & - & - & - & - \\
\hline 26 & city of Kyiv & 60035 & 7957 & 48905 & 1305 & 30 & 243 & 1595 \\
\hline
\end{tabular}

The information on the presence of foreigners in Ukraine is important. The data from 2018 clearly correlates with the military situation that is characteristic of the eastern regions of the country. According to the official statistics, tour operators did not serve foreign tourists in 13 regions of Ukraine (Vinnytsia, Dnipropetrovsk, Zhytomyr, Kirovohrad, Luhansk, Mykolaiv, Poltava, Rivne, Sumy, Ternopil, Kherson, Khmelnytskyi and Chernihiv regions). Nonetheless, the same number of administrative territories was officially attractive to foreign tourists. The undisputed 
leaders according to the arrivals are the city of Kyiv, as well as Lviv and IvanoFrankivsk regions (they account for $91.5 \%$ of foreign tourists served by travel agents). Among other areas, Odessa region stands out, accounting for $2.5 \%$ of tourists served by Ukrainian travel agents.

To some extent, these statistics cause concerns. After all, we can agree that tourists do not visit the frontline areas for security purposes. But the absence of organized tourists in Vinnytsia, Poltava, Rivne, Ternopil or Khmelnitskyi regions causes doubts. Each of them has significant tourist destinations and forms the appropriate tourist infrastructure. In general, this is a problem of transparent evaluation of international tourism flows statistics, which allows to objectively evaluating the tourist attractiveness of individual territories of the state.

Conclusion. It is possible to state that globalization, as a complex and dynamic process, contributes directly or indirectly to tourism development. Making economic, social, political and even cultural changes, globalization forms a single global market and significantly facilitates the movement of capital, goods and people. Globalization also has its intangible aspect, which is providing access to information and modern forms of communication and stimulating spatial mobility of the population. It provides a free flow of ideas that show individuals new attitudes and behaviours. International tourist destinations are influenced by both external and internal factors, but the environment responds differently to the strength and extent of their impact.

Increasing population mobility and the impact of outbound tourism development are some of the main consequences of globalization. The study showed that the geography of foreign tourists' interest in Ukraine is expanding. To a certain extent, this can be justified by the war, which significantly reoriented the composition and directions of international tourism flows in Ukraine. This trend is likely to continue in the future.

\section{REFERENCES}

1. Alvarez, M. and Asugman, G. (2006). Explorers versus planners: a study of Turkish tourists. In: Annals of Tourism Research, Vol. 33, No. 2, pp. 173-182. DOI: http://dx.doi.org/10.1016/j.annals.2005.12.001

2. Bauman, Z. (1999). Globalization. The human consequences, Cambridge Malden, MA: Polity Press in association with Blackwell Publisher Ltd.

3. Burns, P.M. and Novelli, M. (2008). Tourism and mobilities: local-global connections, CABI.

4. Dłużewska, A., 2009: Społeczno-kulturowe dysfunkcje turystyczne w krajach islamu (The socio-cultural dysfunctions of tourism in Islamic countries - in Polish), Warszawa: Wydawnictwo Uniwersytetu Warszawskiego 
5. Golka, M. (1999). Cywilizacja, Europa, globalizacja (The civilization, Europe, globalization - in Polish), Poznań: Wydawnictwo Fundacji Humaniora.

6. Hall, C.A. and Lew, M.A., 2009: Understanding and managing tourism impacts: an integrated approach, Abingdon: Taylor \& Francis.

7. Hołowiecka B., Grzelak-Kostulska E. (2013). Globalisation as a major factor modifying the patterns of tourism activity. Bulletin of Geography. Socioeconomic Series, No. 21, pp. 49-60.

8. Korol, O. (2018). International tourism flows: socio-geographical aspects of formation and geospatial distribution: monograph / O.D. Korol. - Chernivtsi: Chernivtsi Y. Fedkovych National university, 2018. - 512 p.

9. Kuzyshyn A., (2019). International tourism business. Educational edition. Ternopil: V. Hnatiuk TNPU, 2019. 146 p.

10. Kuzyshyn A., Maryniak J. (2010), Assessment of tourism attractiveness of Western Ukrainian regions in the light of international tourist arrivals // Scientific Bulletin of Chernivtsi University: Collection of scientific papers, No. 519-520: Geography. - Chernivtsi: Chernivtsi National University, pp. 141-145.

11. Report of the World Economic Forum in Tourism for 2019. Retrieved from: http://www3.weforum.org/docs/WEF_TTCR_2019.pdf

12. Romanova, H. (2019). In the area of special attraction. Due to which the number of foreign tourists in Ukraine is increasing. Retrieved from: https://nv.ua/ukr/ biz/markets/inozemniy-turizm-ukrajina-pidnyalasya-v-reytingu-turistichnojiprivablivosti-novini-ukrajini-50047420.html

13. Pohuda N.V., Rozmetova O.G. (2018). The current state of the tourism market of Ukraine: evaluation and prospects / «Effective economy», vol. 10. DOI: $10.32702 / 2307-2105-2018.10 .57$

14. Tourism activity in Ukraine in 2018: statistical information. Retrieved from: https://ukrstat.org/uk/operativ/operativ2019/tyr/tyr_dil/arch_tyr_dil.htm

15. Wahab, S.P. and Cooper, Ch. (2001). Tourism in the age of globalization, London: Routledge. 